\title{
Molecular characterization of a grapevine leafroll-associated virus 4 from Slovenian vineyards
}

\author{
M. ŠTRUKELJ, I. MAVRIČ PLEŠKO, G. UREK
}

Plant Protection Department, Agricultural Institute of Slovenia, Hacquetova ulica 17, SI-1000 Ljubljana, Slovenia

Received July 31, 2015; accepted April 21, 2016

\begin{abstract}
Summary. - During a survey conducted in vineyards in Slovenia, variety of grapevine leafroll disease symptoms were observed. Mixed infection with grapevine leafroll-associated viruses 3 and 4 (GLRaV-3, -4$)$ in two grapevines from a vineyard in south-western part of Slovenia was confirmed by DAS-ELISA in 2010. The 3'final 1769 nucleotides of the Slovenian GLRaV-4 isolate were assembled from amplicons obtained by IC RTPCR. The complete coat protein (CP) and p23 gene sequences were compared with other GLRaV-4 sequences from GenBank. Results showed that CP and p23 amino acid sequences of Slovenian variant (055-SI) are 88\% and 85\%, respectively, identical to corresponding genes of reference sequence GLRaV-4 LR106 (GenBank Acc. No. FJ467503). Phylogenetic analyses show that Slovenian variant clusters together with other corresponding strains of GLRaV-4. The sequencing results show great variability of the N-terminal part of the CP sequence indicating that this part of the genome is not suitable for molecular detection of the virus. To our knowledge this is also the first report of GLRaV-4 in Slovenian vineyards.
\end{abstract}

Keywords: Ampelovirus; Closteroviridae; CP; GLRaV-4; p23; Slovenia

\section{Introduction}

Grapevine leafroll disease (GLD) is one of the most widespread and damaging diseases in all major grapevinegrowing areas in the world. It is considered to be a major virus disease of grapevine.

Mild downward rolling and premature reddening or yellowing of the lower leaves in red and white grapevine varieties are the first symptoms of GLD. In summer and fall symptoms progress and cause downward rolling of leaves and phloem disruption. The disease affects fruit quality and leads to significant decrease in yield (Martelli and BoudonPadieu, 2006; Moutinho-Pereira et al., 2012).

GLD is caused by different grapevine leafroll-associated viruses (GLRaVs) transmitted by scale insects in semi-

E-mail: melita.strukelj@kis.si; phone: +38612805176.

Abbreviations: $\mathrm{CP}=$ coat protein; $\mathrm{GLRaV}=$ grapevine leafrollassociated virus; HSP70h = heat-shock protein 70 homolog; RdRp $=$ RNA dependent RNA polymerase persistent manner. Most of these viruses belong to the genus Ampelovirus (GLRaV-1, -3, -4), GLRaV-2 is assigned to the genus Closterovirus and GLRaV-7 is a member of the new genus Velarivirus, all in the family Closteroviridae (Al Rwahnih et al., 2012; Martelli et al., 2012).

According to the current taxonomy, the genus Ampelovirus is split into two subgroups (Martelli et al., 2012). Among grapevine-infecting viruses, GLRaV-1 and -3 are members of subgroup I, and GLRaV-4 is a member of subgroup II. GLRaV-5, -6, -9, -De, -Pr and -Car used to be distinct species within the genus Ampelovirus. After the complete genomic sequences have been obtained for different members of subgroup II, GLRaV-5, -6, -9, -De, -Car and -Pr were recognised as genetically divergent strains of GLRaV-4 (Abou GhanemSabanadzovic et al., 2012; Martelli et al., 2012; Thompson et al., 2012). The last variant was published in GenBank in 2014 and was named GLRaV-4 strain 9, already according to the new taxonomy.

GLRaV-4 has been reported from many grapevine-growing countries worldwide (Martelli, 2014). In Europe it was reported from Portugal (Esteves et al., 2012), Spain (Padilla 
et al., 2010), France (Thompson et al., 2012), Switzerland (Reynard et al., 2015), Italy (Giampetruzzi et al., 2011; Rizzo et al., 2014), Greece (Maliogka et al., 2008) and Turkey (Buzkan et al., 2010). Except Switzerland, there are no reports of GLRaV-4 from Central and Eastern Europe.

In this work we report about the first finding of GLRaV-4 in Slovenia, about molecular characterisation of the 3' end of the genome and about the relationship of Slovenian isolate with other variants of GLRaV4.

\section{Materials and Methods}

Plant material and RNA extraction. Leaves from 70 field-grown grapevine plants were collected in autumn 2010 in one vineyard from south western part of Slovenia. The presence of arabis mosaic virus (ArMV), cherry leaf roll virus (CLRV), GLRaV-1, GLRaV-2, GLRaV-3, GLRaV-4-9, grapevine fanleaf virus (GFLV), grapevine fleck virus (GFkV), grapevine virus A (GVA), raspberry bushy dwarf virus (RBDV), raspberry ringspot virus (RRSV), strawberry latent ringspot virus (SLRSV), tobacco ringspot virus (TRSV), tomato black ring virus (TBRV) and tomato ringspot virus (ToRSV) was determined by DAS-ELISA according to the manufacturer's instructions (BIOREBA AG, Switzerland). One of two GLRaV-4 positive samples was used for further molecular characterization.

Immunocapture RT. PCR reaction tubes were pre-coated with anti-GLRaV-4-9 IgG (BIOREBA AG, Switzerland), washed with ELISA washing buffer and $50 \mu$ of plant sap were incubated overnight. RT reactions were performed in a final volume of $25 \mu \mathrm{l}$ containing 1X M-MLV RT Buffer (Promega, USA), 2 mmol/l dNTPs, 200 U M-MLV Reverse Transcriptase (Promega, USA), $40 \mathrm{U}$ RNasin (Promega, USA) and 50 pmol of reverse gene specific primer. The RT reactions were incubated at $42^{\circ} \mathrm{C}$ for $1 \mathrm{hr}$.

PCR, cloning, sequencing and sequence analysis. PCR reactions were performed in a final volume of $25 \mu \mathrm{l}$ using 5X KAPA2G Buffer A (Kapa Biosystems, South Africa), 0.4 mmol/l dNTPs,
5 U KAPA2G Robust HotStart DNA polymerase (Kapa Biosystems, South Africa) and 50 pmol of each of gene-specific primers (Table 1). The primers from this work were designed using Primer3 software (Ye et al., 2012) based on GenBank sequences FJ467503 (GLRaV-4 LR106) and KJ810572 (GLRaV-4 strain 9), targeting coat protein (CP) and p23 gene. The amplification conditions comprised an initial denaturation at $94^{\circ} \mathrm{C}$ for 4 min followed by 40 cycles of denaturation at $94^{\circ} \mathrm{C}$ for $30 \mathrm{sec}$, annealing at $56^{\circ} \mathrm{C}$ (or $50^{\circ} \mathrm{C}$ for LRamp-F/R) for $45 \mathrm{sec}$, extension at $72^{\circ} \mathrm{C}$ for $1 \mathrm{~min}$ and a final extension at $72^{\circ} \mathrm{C}$ for $7 \mathrm{~min}$. PCR products were visualized in $1.2 \%$ agarose gels. Before cloning, PCR products were purified from the gel using a JETQUICK Gel Extraction Spin Kit (Genomed, Germany).

Cloning of purified PCR products was carried out using a pGEM-T Easy Vector System (Promega, USA) and transformed into competent JM-109 Escherichia coli cells (Promega, USA) according to manufacturer's instructions. Colony PCR was used to identify colonies with inserts. Plasmids were purified from selected positive clones using a JETQUICK Plasmid Miniprep Spin Kit (Genomed, Germany). At least three clones for each amplicon were sequenced in both directions at Macrogen (Netherlands) and consensus sequences were assembled. The obtained amplicon sequences were analyzed, aligned and assembled using software BioEdit version 7.0.5.3. The assembled sequence of isolate 055-SI was deposited in the GenBank Acc. No. KM892778. A sequence database was constructed containing the GLRaV-4 sequences available in the GenBank that corresponded in length to the sequence obtained during this work. The sequence of pineapple mealybug wilt-associated virus 1 ( $\mathrm{PMWaV}-1)$ was used as the outgroup for phylogenetic analyses (Table 2). The nucleotide and amino acid sequences were multiple aligned using CLUSTAL W and MUSCLE using default settings from MEGA6. The phylogenetic relationships for each gene dataset were determined with the maximum-likelihood algorithm (ML) of the MEGA6 with 1000 bootstrap replications for both $\mathrm{CP}$ and $\mathrm{p} 23$. A gene-specific model was chosen on the basis of the lowest BIC score of deduced amino acid sequences.

Table 1. GLRaV-4-specific primers used in this study

\begin{tabular}{|c|c|c|c|c|c|}
\hline Target region $^{\mathrm{a}}$ & Primer name & Sequence $5^{\prime}-3^{\prime}$ & Genome position ${ }^{\mathrm{b}}$ & $\begin{array}{l}\text { Product } \\
\text { size (bp) }\end{array}$ & Reference \\
\hline \multirow[t]{4}{*}{$\mathrm{CP}$} & LR4-IR-F1 & TCCGRSCCAYATGAACTTCGA & \multirow{2}{*}{$11920-12921$} & \multirow{2}{*}{1001} & This work \\
\hline & LR-9-CP-R & TGAGGCGTCGTAACCGAACAATCT & & & Jerugula et al., 2008 \\
\hline & LR4ms-CP-F & CGTCTGGGAAACTGGAAGTGA & \multirow{2}{*}{$12800-13070$} & \multirow{2}{*}{270} & \multirow{2}{*}{ This work } \\
\hline & LR4ms-CP-R & ACGAAAATATGAGAAGTCACAGAC & & & \\
\hline \multirow[t]{2}{*}{ CP, p23 } & LR4-56-MS4-F & GTGGCCATAAACAAACCGTC & \multirow{2}{*}{$12946-13370$} & \multirow{2}{*}{424} & \multirow{2}{*}{ This work } \\
\hline & LR4-56-MS4-R & GGAAAAGGTACCGAACGTTT & & & \\
\hline \multirow[t]{2}{*}{$\mathrm{p} 23$} & LRamp-F & ATTTAGGTAATGTTGTAGCTAC & \multirow{2}{*}{ 13274-13758 } & \multirow{2}{*}{484} & \multirow{2}{*}{$\begin{array}{l}\text { Abou Ghanem-Saba- } \\
\text { nadzovic et al., } 2012\end{array}$} \\
\hline & LRamp-R & TATCCTCAGWGAGGAARCGG & & & \\
\hline
\end{tabular}

${ }^{\mathrm{a}} \mathrm{CP}=$ coat protein, $\mathrm{p} 23$ = open reading frame 6 , ${ }^{\mathrm{b}}$ Positions of the primers in the genome of GLRaV-4 sequence FJ467503. 
Table 2. GLRaV-4, its strains and their GenBank Acc. Nos of coat protein and p23 gene sequences used in this study

\begin{tabular}{|c|c|c|c|c|}
\hline Virus/Strain & Isolate & GenBank Acc. No. & Country & Reference \\
\hline GLRaV-4 & LR106 & FJ467503 & USA & Abou Ghanem-Sabanadzovic et al., 2012 \\
\hline GLRaV-4 & $\mathrm{Y} 252-\mathrm{IL}^{\mathrm{a}}$ & AM176759 & Israel & Saldarelli et al., 2006 \\
\hline GLRaV-4 & Y253-TK & AM162279 & Turkey & Saldarelli et al., 2006 \\
\hline GLRaV-4 & 055-SI & KM892778 & Slovenia & This study \\
\hline GLRaV-4 & Rul & AB720874 & Japan & Ito et al., 2013 \\
\hline GLRaV-4 & $\mathrm{Ru} 2$ & AB720875 & Japan & Ito et al., 2013 \\
\hline GLRaV-4 strain 5 & GLRaV-5 & AF233934 & & Good \& Monis, 2001 \\
\hline GLRaV-4 strain 5 & $1050-02$ & JX513893 & Canada & Unpublished \\
\hline GLRaV-4 strain 5 & Y217 & FR822696 & France & Thompson et al., 2012 \\
\hline GLRaV-4 strain 6 & Estellat & FJ467504 & USA & Abou Ghanem-Sabanadzovic et al., 2012 \\
\hline GLRaV-4 strain 9 & GLRaV-9 & AY297819 & & Unpublished \\
\hline GLRaV-4 strain 9 & strain 9 & KJ810572 & Spain & Unpublished \\
\hline GLRaV-4 strain Car & & FJ907331 & USA & Abou Ghanem-Sabanadzovic et al., 2010 \\
\hline GLRaV-4 strain De & & AM494935 & Greece & Maliogka et al., 2008 \\
\hline GLRaV-4 strain Pr & & AM182328 & Greece & Maliogka et al., 2008 \\
\hline PMWaV-1 & & AF414119 & & Melzer et al., 2008 \\
\hline
\end{tabular}

${ }^{\text {aSequence of }}$ 23 gene is not available in GenBank.

Table 3. Nucleotide and amino acid sequence identity (\%) of the coat protein (below and above the diagonal, respectively) between Slovenian variant and corresponding sequences of GLRaV-4

\begin{tabular}{|c|c|c|c|c|c|c|c|c|c|c|c|c|c|c|c|c|c|}
\hline & & 1 & 2 & 3 & 4 & 5 & 6 & 7 & 8 & 9 & 10 & 11 & 12 & 13 & 14 & 15 & 16 \\
\hline LR106 & 1 & & 94 & 94 & 88 & 74 & 76 & 83 & 82 & 83 & 81 & 81 & 81 & 77 & 77 & 80 & 51 \\
\hline Y252-IL & 2 & 93 & & 99 & 88 & 75 & 76 & 81 & 82 & 81 & 81 & 81 & 82 & 78 & 79 & 80 & 50 \\
\hline Y253-TK & 3 & 90 & 95 & & 88 & 74 & 75 & 81 & 82 & 81 & 81 & 80 & 81 & 78 & 78 & 80 & 51 \\
\hline 055-SI & 4 & 81 & 81 & 82 & & 76 & 78 & 79 & 80 & 79 & 81 & 81 & 81 & 76 & 77 & 81 & 50 \\
\hline Rul & 5 & 68 & 68 & 67 & 69 & & 93 & 74 & 73 & 74 & 72 & 71 & 73 & 74 & 73 & 74 & 53 \\
\hline Ru2 & 6 & 70 & 70 & 70 & 70 & 88 & & 75 & 75 & 75 & 74 & 73 & 74 & 74 & 75 & 75 & 53 \\
\hline GLRaV-5 & 7 & 71 & 73 & 73 & 72 & 67 & 68 & & 96 & 99 & 85 & 87 & 85 & 78 & 77 & 86 & 52 \\
\hline $1050-02$ & 8 & 72 & 74 & 73 & 73 & 68 & 69 & 94 & & 96 & 85 & 86 & 85 & 78 & 77 & 85 & 52 \\
\hline Y217 & 9 & 71 & 73 & 73 & 73 & 67 & 68 & 99 & 94 & & 85 & 87 & 85 & 78 & 77 & 86 & 52 \\
\hline-6 Est & 10 & 73 & 72 & 72 & 72 & 68 & 68 & 74 & 74 & 75 & & 84 & 83 & 78 & 75 & 91 & 51 \\
\hline GLRaV-9 & 11 & 72 & 72 & 72 & 74 & 66 & 67 & 80 & 79 & 80 & 76 & & 97 & 78 & 77 & 86 & 50 \\
\hline strain 9 & 12 & 72 & 72 & 72 & 74 & 66 & 68 & 81 & 79 & 81 & 77 & 97 & & 78 & 76 & 85 & 51 \\
\hline GLRaV-Car & 13 & 70 & 69 & 69 & 68 & 67 & 68 & 68 & 69 & 68 & 69 & 68 & 68 & & 75 & 75 & 52 \\
\hline GLRaV-Pr & 14 & 70 & 70 & 71 & 68 & 64 & 67 & 69 & 68 & 69 & 69 & 67 & 68 & 68 & & 75 & 51 \\
\hline -De & 15 & 71 & 72 & 72 & 73 & 68 & 69 & 75 & 74 & 75 & 85 & 75 & 76 & 69 & 68 & & 51 \\
\hline PMWaV-1 & 16 & 55 & 55 & 55 & 56 & 57 & 56 & 56 & 56 & 56 & 55 & 55 & 55 & 60 & 58 & 56 & \\
\hline
\end{tabular}

\section{Results and Discussion}

Grapevine leafroll disease is known to be present in Slovenia. It is mostly caused by GLRaV-1 and GLRaV-3 (Mavrič Pleško et al., 2011; Štrukelj et al., 2013). Of other GLRaVs, GLRaV-2 was found by ELISA and electron microscopy in 9 out of 210 grapevines from selection vineyards in southwestern part of Slovenia (Tomažič et al., 2008). Also GLRaV-6 was occasionally found by ELISA but its presence has never been confirmed by other methods (Čepin, 2011).
In this study, GLRaV-4 was detected in mixed infection with GLRaV-3 in two out of 70 grapevine leaf samples by DAS-ELISA. ArMV, CLRV, GFkV, GFLV, GLRaV-1, GLRaV-2, GVA, RBDV, RRSV, SLRSV, TBRV, ToRSV and TRSV tested negative by DAS-ELISA. One of GLRaV-4positive samples was used for further molecular characterization and the immunocapture RT-PCR was used to ensure specific detection of GLRaV-4.

Evolutionary relationships in the family Closteroviridae are studied on the basis of the molecular divergence 
of RNA-dependent RNA polymerase (RdRp), heat-shock protein 70 homolog (HSP70h) and coat protein (CP) gene (Dolja et al., 2006). Species demarcation criteria within the genus Ampelovirus are at least $75 \%$ amino acid identity of RdRp, HSP70h and CP (Martelli et al., 2011). The assembled sequence of Slovenian GLRaV-4 isolate 055 -SI covered the 1769 nucleotides of $3^{\prime}$-end of the genome containing part of p60, whole CP and p23 gene and 42 nucleotides of $3^{\prime}$ noncoding region. The $\mathrm{CP}$ and $\mathrm{p} 23$ were compared with 16 CP sequences (Table 3 ) and 13 sequences of p23 (Table 4) of subgroup II ampeloviruses.

The CP sequence of 055 -SI consists of 789 nucleotides. It shows the highest identity with the CP sequences of LR106, Y235-TK and Y252-IL (81\%-82\%). Identity with other sequences is 69\%-74\% (Ru1, Ru2, GLRaV-5, 1050-02, Y217, -6Est, GLRaV-9, strain 9 and -De) and 68\% (-Car and -Pr) (Table 3). The deduced amino acid sequence identity of CP (262 aa) is $88 \%$ (LR106, Y235-TK and Y252-IL), 79\%-81\% (GLRaV-5, 1050-02, Y217, -6Est, GLRaV-9, strain 9 and -De) and 76\%-78\% (Ru1, Ru2, -Car and -Pr) (Table 3). Comparison of deduced amino acid sequence shows that $\mathrm{CP}$ of $055-\mathrm{SI}$ is 10 aa shorter than three most closely related GLRaV-4 CP sequences. Furthermore, comparison of the 234 aa of the C-terminal part of the CP shows that 055-SI shares $95 \%-97 \%$ identity with them and $82 \%-89 \%$ with all other sequences (data not shown). Most of the mismatches are located in the N-terminal part of the CP, which is 29-39 amino acids long, depending on the isolate. The sequence identity for the $\mathrm{N}$-terminal part of $\mathrm{CP}$ among isolates ranges between 13\% (Ru1 and GLRaV-9) and 97\% (strain 5; GLRaV-5 and Y217). On that part of CP, identity of 055-SI comparing with others is $42 \%$ (Y235-TK and Y252-IL) and 24\% (GLRaV-5 and Y217) (data not shown). Saldarelli et al. (2006) already reported that the N-terminal part of the
$\mathrm{CP}$ is the most heterogeneous part of the CP of compared variants and only few differences can be found in the rest of the CP. Similar to them we had problems amplifying the 5 -end of the CP sequence using different primer pairs. The comparison of these primers with the obtained sequence of 055 -SI showed 3 to 7 mismatches, which prevented the amplification of the target product.

Gene 23 is separated by $33 \mathrm{nt}$ from the CP, the same as in all other GLRaV-4 strains. The p23 gene of 055-SI consists of $624 \mathrm{nt}$ and shows $87 \%$ identity with LR106, 79\%-81\% with GLRaV-5, 1050-02, Y217, -6Est, GLRaV-9 and strain 9, 70\% with -Pr and 61\%-62\% with Ru1, Ru2 and -Car (Table 4). The identity of deduced protein sequence of 207 aa is $85 \%$ with LR106, 75\%-76\% with GLRaV-5, 1050-02, Y217, -6Est, GLRaV-9 and strain 9, 65\% with -Pr and 56\%-57\% with Ru1, Ru2 and -Car (Table 4).

Phylogenetic analyses of ampeloviruses have mainly been made on the HSP70h and CP genes (Abou Ghanem-Sabanadzovic et al., 2012; Martelli et al., 2012; Ito et al., 2013) but phylogenetic trees obtained from six different ampeloviruses proteins (Mt/Hel, RdRp, HSP70h, CP, p60 and p23) showed similar topologies (Thompson et al., 2012). The CP- and p23-based phylogenetic trees made during our study show five clusters corresponding to five strains of GLRaV-4 (-4, $-5,-6,-9$ and -De), -Car and -Pr. 055-SI is grouped together with three GLRaV-4 isolates (LR106, Y252-IL and Y253-TK). In both phylogenetic trees, Ru1 and Ru2 grouped together, -Car and -Pr appear to be the most diverse members of subgroup II ampeloviruses (Fig. 1 and 2). They indicate a wide and complex genetic diversity of GLRaV-4. Results of our study are in agreement with previously published studies on complete or partial sequences of these two genes (Abou Ghanem-Sabanadzovic et al., 2012; Martelli et al., 2012; Thompson et al., 2012; Ito et al., 2013).

Table 4. Nucleotide and amino acid sequence identity (\%) of the p23 gene (below and above the diagonal, respectively) between Slovenian variant and corresponding sequences of GLRaV-4

\begin{tabular}{lrrrrrrrrrrrrrr}
\hline & & $\mathbf{1}$ & $\mathbf{2}$ & $\mathbf{3}$ & $\mathbf{4}$ & $\mathbf{5}$ & $\mathbf{6}$ & $\mathbf{7}$ & $\mathbf{8}$ & $\mathbf{9}$ & $\mathbf{1 0}$ & $\mathbf{1 1}$ & $\mathbf{1 2}$ & $\mathbf{1 3}$ \\
\hline LR106 & $\mathbf{1}$ & & 85 & 52 & 52 & 71 & 70 & 71 & 71 & 70 & 70 & 52 & 62 & 37 \\
055-SI & $\mathbf{2}$ & 87 & & 57 & 56 & 76 & 75 & 76 & 76 & 75 & 75 & 57 & 65 & 38 \\
Ru1 & $\mathbf{3}$ & 60 & 61 & & 87 & 53 & 52 & 53 & 54 & 54 & 53 & 55 & 56 & 38 \\
Ru2 & $\mathbf{4}$ & 61 & 61 & 88 & & 52 & 53 & 52 & 53 & 54 & 52 & 55 & 55 & 38 \\
GLRaV-5 & $\mathbf{5}$ & 79 & 80 & 58 & 60 & & 94 & 100 & 83 & 92 & 93 & 56 & 62 & 40 \\
1050-02 & $\mathbf{6}$ & 79 & 81 & 58 & 59 & 96 & & 94 & 83 & 89 & 90 & 56 & 61 & 39 \\
Y217 & $\mathbf{7}$ & 79 & 81 & 58 & 59 & 99 & 96 & & 83 & 92 & 93 & 56 & 62 & 40 \\
-6Est & $\mathbf{8}$ & 77 & 79 & 58 & 59 & 85 & 85 & 85 & & 86 & 85 & 59 & 62 & 38 \\
GLRaV-9 & $\mathbf{9}$ & 79 & 80 & 59 & 59 & 91 & 89 & 90 & 85 & & 97 & 57 & 62 & 40 \\
strain 9 & $\mathbf{1 0}$ & 78 & 80 & 58 & 58 & 92 & 90 & 92 & 85 & 97 & 63 \\
GLRaV-Car & $\mathbf{1 1}$ & 60 & 62 & 60 & 59 & 61 & 61 & 61 & 63 & 62 & 61 \\
GLRaV-Pr & $\mathbf{1 2}$ & 69 & 70 & 61 & 59 & 68 & 68 & 68 & 70 & 67 & 69 & 59 \\
PMWaV-1 & $\mathbf{1 3}$ & 46 & 46 & 46 & 45 & 46 & 45 & 46 & 46 & 45 & 45 & 48 & 50 \\
\hline
\end{tabular}




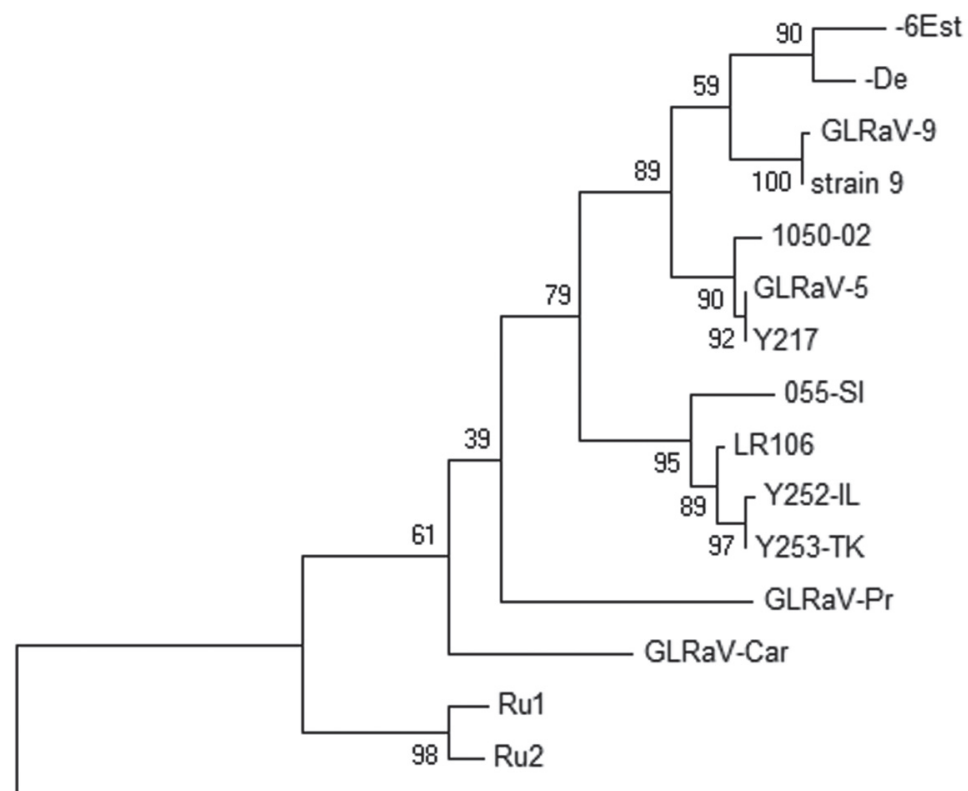

PMWaV-1

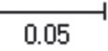

Fig. 1

Phylogenetic tree showing the relationship between GLRaV-4 strains based on homologous amino acid sequences corresponding to the CP datasets PMWaV-1 was used as an out-group. The tree was constructed by the maximum-likelihood (ML) method. Bootstrap values of 1000 replicates are shown on the nodes. The bar represents 0.05 amino acid changes per site and branch lengths are proportional to the genetic distances.

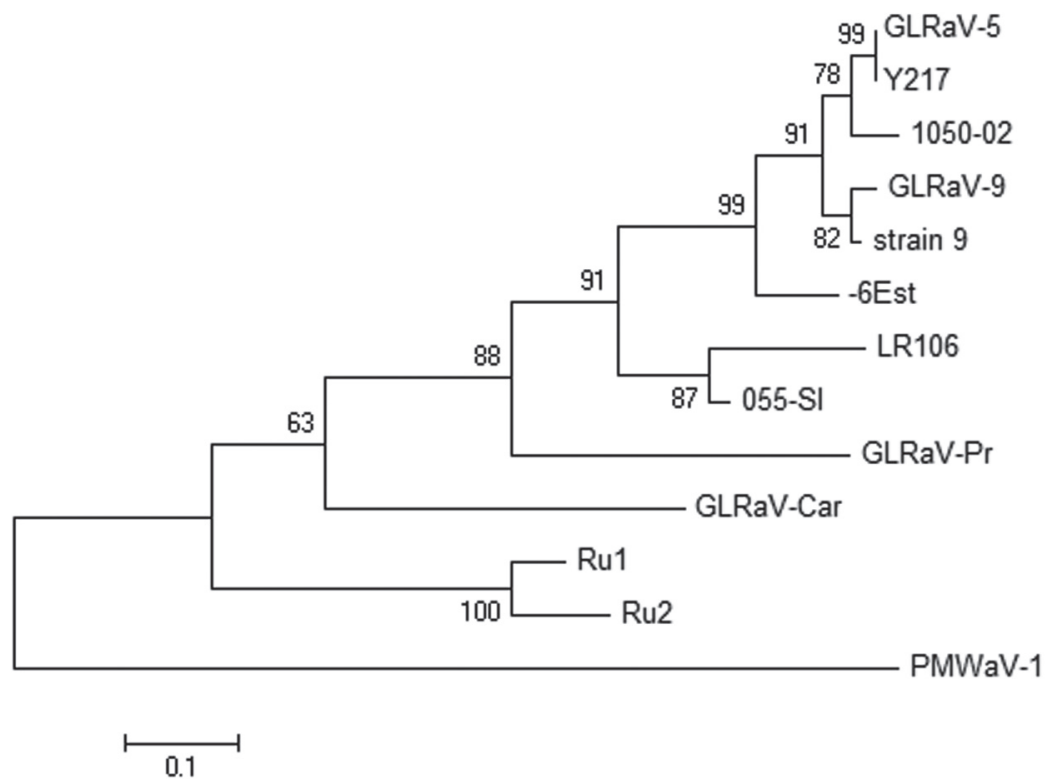

Fig. 2

Phylogenetic tree showing the relationship between GLRaV-4 strains based on homologous amino acid sequences corresponding to the p23 gene datasets

PMWaV-1 was used as an out-group. The tree was constructed by the maximum-likelihood (ML) method. Bootstrap values of 1000 replicates are shown on the nodes. The bar represents 0.1 amino acid changes per site and branch lengths are proportional to the genetic distances. 
In this paper we reported about the first finding and partial molecular characterization of GLRaV-4 in Slovenia. The CP sequence of our isolate indicates a great variability of $\mathrm{N}$-terminal part of the CP as was already observed by Saldarelli et al. (2006). These differences did not interfere with the serological detection of the virus, but caused difficulties in molecular characterization. The information about the great variability in the N-terminal region of the CP is important for further development of molecular diagnostic tests of GLRaV-4.

Acknowledgements. This work was financially supported by the Slovenian Research (PhD scholarship and programme P4-0072) and by FP7 Project CropSustaIn (FP7-REGPOT-CT2012-316205).

\section{References}

Abou Ghanem-Sabanadzovic N, Sabanadzovic S, Gugerli P, Rowhani A (2012): Genome organization, serology and phylogeny of Grapevine leafroll-associated virus 4 and 6: Taxonomic implications. Virus Res. 163, 120-128. http:// dx.doi.org/10.1016/j.virusres.2011.09.001

Abou Ghanem-Sabanadzovic N, Sabanadzovic S, Uyemoto JK, Golino D, Rowhani A (2010): A putative new ampelovirus associated with grapevine leafroll disease. Arch. Virol. 15, 1871-1876. http://dx.doi.org/10.1007/s00705010-0773-2

Al Rwahnih M, Dolja VV, Daubert S, Koonin EV, Rowhani A (2012): Genomic and biological analysis of Grapevine leafrollassociated virus 7 reveals a possible new genus within the family Closteroviridae. Virus Res. 163, 302-309. http:// dx.doi.org/10.1016/j.virusres.2011.10.018

Buzkan N, Karadağ S, Kaya A, Baloğlu S, Minifra A, Ben-Dov Y (2010): First report of the Occurrence of Grapevine leafroll-associated virus 5 in Turkish Vineyards. J. Phytopathol. 158, 448-449. http://dx.doi.org/10.1111/j.14390434.2009.01634.x

Čepin U (2011): Genetic variability and detection of grapevine fanleaf virus (GFLV). Ph.D. Thesis. Biotechnical faculty, University of Ljubljana, SLO.

Dolja VV, Kreuze JF, Valkonen JPT (2006): Comparative and functional genomics of closteroviruses. Virus Res. 117, 38-51. http://dx.doi.org/10.1016/j.virusres.2006.02.002

Esteves F, Teixeira Santos M, Eiras-Dias JE, Fonseca F (2012): Occurrence of grapevine leafroll-associated virus 5 in Portugal: genetic variability and population structure in field-grown grapevines. Arch. Virol. 157, 1747-1765. http://dx.doi.org/10.1007/s00705-012-1371-2

Giampetruzzi A, Chiumenti M, Roberto R, Pirolo C, Minafra A, Saldarelli P (2011): First detection of grapevine leafrollassociated virus 9 in Italy. J. Plant Pathol. 93 (Supplement), S4.63-S4.89.

Good X, Monis J (2001): Partial genome organization, identification of the coat proteine gene, and detection of Grapevine leafroll-associated virus-5. Phytopathology 91, 274-281. http://dx.doi.org/10.1094/PHYTO.2001.91.3.274
Ito T, Nakaune R, Nakano M, Suzaki K (2013): Novel variants of grapevine leafroll-associated virus 4 and 7 detected from a grapevine showing leafroll symptoms. Arch. Virol. 158, 273-275. http://dx.doi.org/10.1007/s00705-012-1444-2

Maliogka VI, Dovas CI, Katis NI (2008): Evolutionary relationships of virus species belonging to a distinct lineage within the Ampelovirus genus. Virus Res. 135, 125-135. http:// dx.doi.org/10.1016/j.virusres.2008.02.015

Martelli GP (2014): Grapevine leafroll. J. Plant Pathol. 96 (Supplement), 51-70.

Martelli GP, Abou Ghanem-Sabanadzovic N, Agranovsky AA, Al Rwahnih M, Dolja VV, Dovas CI, Fuchs M, Gugerli P, $\mathrm{Hu}$ JS, Jelkmann W, Katis NI, Maliogka VI, Malzer MJ, Menzel W, Minifra A, Rott ME, Rowhani A, Sabanadzovic S, Saldarelli P (2012): Taxonomic revision of the family Closteroviridae with special reference to the grapevine leafroll-associated members of the genus Ampelovirus and the putative species unassigned to the family. J. Plant Pathol. 94, 7-19.

Martelli GP, Agranovsky AA, Bar-Joseph M, Boscia D, Candresse T, Coutts RHA, Dolja VV, Hu JS, Jelkmann W, Karasev AV, Martin RR, Minafra A, Namba S, Vetten HJ (2011): Family Closteroviridae. In King A, Adams MJ, Carstens EB, Lefkowitz E (Ed.): Virus Taxonomy. Ninth Report of the International Committee on Taxonomy of Viruses, Academic Press, Amsterdam, The Netherlands, pp. 987-1001.

Martelli GP, Boudon-Padieu E (2006): Directory of infectious diseases of grapevines. In Martelli GP, Boudon-Padieu E (Ed.): Options Mediterraneennes. Vol. 55. CIHEAM, Bari.

Mavrič Pleško I, Viršček Marn M, Žežlina I, Urek G (2011): Transmission of grapevine leafroll-associated virus 1 (GLRaV-1) by scale insect Neolpulvinaria innumerabilis. In Maček J, Trdan S (Ed.): Abstract Volume. Ljubljana: Plant Protection Society of Slovenia, pp. 47-48.

Melzer MJ, Sether DM, Karasev AV, Borth W, Hu JS (2008): Complete nucleotide sequence and genome organization of pineapple mealybug wilt-associated virus-1. Arch. Virol. 153, 707-714. http://dx.doi.org/10.1007/s00705$\underline{008-0051-8}$

Moutinho-Pereira J, Correia CM, Goncalves B, Bacelar EA, Coutinho JF, Ferreira HF, Lousada JL, Cortez MI (2012): Impacts of leafroll-associated viruses (GLRaV-1 and -3) on the physiology of the Portugese grapevine cultivar "Touriga Nacional' growing under field conditions. Ann. Appl. Biol. 160, 237-249. http://dx.doi.org/10.1111/j.17447348.2012.00536.x

Padilla CV, Cretazzo E, López N, García de Rosa B, Padilla V, Velasco L (2010): First report of Grapevine leafroll-associated virus 4 (GLRaV-4) in Spain. New Dis. Rep. 21, 21. http:// dx.doi.org/10.5197/j.2044-0588.2010.021.021

Reynard JS, Schneeberger PHH, Frey JR, Schaerer S (2015): Biological, Serological, and Molecular Characterization of a Highly Divergent Strain of Grapevine leafroll-associated virus 4 Causing Grapevine Leafroll Disease. Phytopathology 105, 1262-1269. http://dx.doi.org/10.1094/PHYTO12-14-0386-R 
Rizzo D, Luvisi A, Stefani L, Paoli M, Marchi G, Panattoni A, Materazzi A (2014): First report of grapevine leafroll associated virus-4 strain 5 in Italy. J. Plant Pathol. 96 (Supplement), 129

Saldarelli P, Cornuet P, Vigne E, Talas F, Bronnenkant I, Dridi AM, Andret-Link P, Boscia D, Gugerli P, Fuchs M, Martelli GP (2006): Partial characterization of two divergent variants of Grapevine leafroll-associated virus 4. J. Plant Pathol. 88, 203-214.

Štrukelj M, Mavrič Pleško I, Viršček Marn M, Razinger J, Urek G (2013): Scale insects - vectors of grapevine viruses in Primorska. In Trdan S, Maček J (Ed.): Lectures and Papers Presented at the 11th Slovenian Conference on Plant Protection with International Participation (and The Round Table of Risks Reduction in Phyto-pharmaceutical Products Use in the Frame of CropSustaIn Project),
Bled. Ljubljana, Plant Protection Society of Slovenia, pp. 344-347.

Thompson JR, Fuchs M, Perry KL (2012): Genomic analysis of grapevine leafroll associated virus-5 and related viruses. Virus Res. 163, 19-27. http://dx.doi.org/10.1016/j. virusres.2011.08.006

Tomažič I, Mavrič Pleško I, Petrovič N, Ravnikar M, KorošecKoruza Z (2008): Introduction of Grapevine virus B and Grapevine leafroll-associated virus 2 testing in sanitary selection of grapevine. Acta Agric. Slov. 91, 75-85. http:// dx.doi.org/10.2478/v10014-008-0008-3

Ye J, Coulouri G, Zaretskaya I, Cutcutache I, Rozen S, Madden T (2012): Primer-BLAST: A tool to design targetspecific primers for polymerase chain reaction. BMC Bioinform. 13, 134. http://dx.doi.org/10.1186/14712105-13-134 